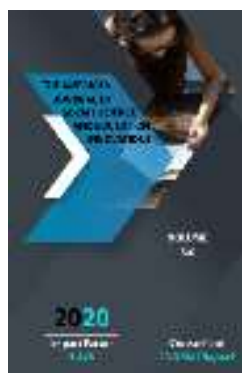

\title{
The Current State Of Preservation Of The Epic Tradition Of Epic Poetry Of South Uzbekistan
}

Journal Website: http://usajournalshub.c om/index,php/tajssei

Nasim Ochilov

Candidate Of Philological Sciences, Associate Professor, Karshi State University, Uzbekistan

\section{ABSTRACT}

The article discusses the specificity of the art of epic poetry, the current state of preservation, the role of bakhshi in the revival of epic traditions, changes in the methods and forms of oral performance of folk epics, factors of national creativity and individual performance in bakhshi repertoire and the article analyzes the breakdown of the epic and its transition to the professional stage, as well as the role of epic memory, knowledge and worldview in the preservation of modern living oral traditions, as well as the current state and fate of epic traditions in the South Uzbekistan oasis.

\section{KEYWORDS}

Epic poetry, epic performance, tradition, epic memory, knowledge, epic worldview, bakhshi, repertoire, globalization, national performance, stage interpretation, epic skill.

\section{INTRODUCTION}

Uzbek folklore seeks to highlight one scientific fact, highlighting epic schools in different regions of the country and defining their specific and common features: the Uzbek folk epic is an integral, perfect, unique phenomenon, and each epic school is an integral part of it. Traditions of epics have gone through different processes in different regions of Uzbekistan. The Southern Uzbekistan oasis is a special event in the history of epic poetry. Therefore, South Uzbekistan can be an important object in the study of the roots, formation, development and extinction of epic poetry. The unique ancient cultural traditions of this oasis undoubtedly played an important role in the development of epic poetry as well. But the forms of mass art that have entered our sociocultural life have led to a change in epic traditions. As the storytelling methods 
changed, he moved onto the stage. The study of such a situation with live oral processes on the example of today's epic traditions plays an important role in the study of the dynamics of the historical-folklore process.

\section{MAIN PART}

The survival and continuation of the art of epic poetry in the processes of live oral performance is associated with the performing abilities of bakhshi, formed within the framework of a stable tradition [1]. Emergence of epic schools and teacherstudent traditions, bakhshi personality and its epic performance, tradition and badiha, collective and individual performance, bakhshi critical approach to their works, bakhshi and his listener, aesthetic views of the epic performer in terms of the power of words and words led to the continuation and creation of his art in a living oral tradition. Such features of the lively creative process testify to the fact that a number of epic centers - dozens of bakhshi schools - have made a worthy contribution to the spiritual development of the people. Samarkand, Bukhara, Tashkent, Fergana, Khorezm, Surkhandarya and Kashkadarya epic schools are vivid examples of this [2].

Although the traditions of epic poetry have developed in different parts of the country and have their own methods and modes of execution, the scientific and technological development of the twentieth century, globalization, accelerated exchange of information, increased public literacy, written literature and other forms of art, its widespread place in cultural life has significantly weakened the former positions of epic poetry. It has led to the extinction of many epic schools in live processes. Because, "The living connection of the Bakhshi generation in the context of oral traditions is the performance of the epic and its existence in everyday life. The extinction of this connection is the extinction of epic schools, the end of oral performance, the different quality of the epic - the live performance, the natural environment that created it, the writing, the artificial reproduction of the complex artistic side of epic life. The absence of such features leads to the absence of an audience that listens to ancient events [3, 4]. However, in the oasis of South Uzbekistan, the art of bakhshi and epic continues to this day. Such circumstances have shaped the stage interpretations of epic performance, to a certain extent the change of eloquent oral performance and traditions. Even the performances of Kara and Chori Umirovs, Shomurod Togaev, Shoberdi Boltaev, Abdunazar Poyonov, Boborayim Mamatmurodov, Jovli Tangirov, Qahhor Rakhimov, Shodmon Bakhshi Khojamberdiev, who saw the teacher and learned the methods of performing the story orally, is conspicuous. Especially when the methods of epic performance move to the stage, individual creative feelings are evident in the depiction of traditional plots, motifs and images. There are cases of fragmentation in the performance of the epic, and such processes shape the bakhshis'ability to approach epic traditions on their own.

It is known that in recent years, the participation of bakhshis in popular events, ceremonies related to the life of the people, the movement to perform excerpts from epics and epics, to evaluate themselves as a modern artist, creates fragmentation in the texts of epics. Such situations reinforce new interpretations of epic performance, a sense of a free approach to the traditional plot. If we pay attention to the texts of the epic performed by Shoberdi Boltaev (performed at 
the wedding of Doston), it changes some episodes of the epic on the basis of the wishes and will of the owners of the house, causing a violation of the national spirit in some imagery. Bakhshi's appreciation of the performer as a free-spirited performer adapts the epic environment and time to the psyche of the homeowners and listeners, and on this basis uses playful weights to encourage them to play and improve the performance of the corresponding texts. During the one-hour performance, he uses "Oyparcha", "Alpomish" and on-demand teams. From the epic "Oyparcha" he performs the image of Oyparcha going to Makkah Madinah to the Shaniyaz king and approaches the traditional text based on the worldview of himself and the owners of the wedding. For example, in Oyparcha's text to Shaniyaz saying "let there be a way for you", such cases are observed [4].

The versions of the epic, written by Umir poet Safarov and Bori Bakhshi Ahmedov, also contain images of Oyparcha pleading that Shoniyoz not go on pilgrimage, and they are dominated by generalization. In particular, in the version of the poet Umir, such a state of mind is reflected in the image spoken in the Oyparcha language [5, 217].

In Shoberdi Bakhshi's version, this image is individualized, and the process of Bakhshi's assessment of the event on the basis of the listener's worldview becomes more pronounced. He even speaks in the tone of a plea to the king Shaniyaz, as he had foreseen an episode of hostility of forty women from the language of the Bakhshi Oyparcha. This is the case in the version of the poet Umir, "Don't you know the traces of the speech?" through his interrogation he tells not the image of forty women hostile to him, but the fate that may have befallen him in his life.
Because the events that can happen in the case of separation are related to the issue of time, opportunity. The poet Umir depicts this image in a folk spirit.

Shoberdi Boltaev's portrayal of the epic Alpomish at the same event shows similar fragmentation. Depending on the circumstances of the wedding and the mood of the participants, Bakhshi connects the events of the epic with the image of Ultontoz's wedding in Alpomish. Bakhshi draws attention to Ultontoz's wedding in the process of describing the actions involved in holding a wedding. It aims to give a dramatic tone to the events through the image of the monument. At the wedding, Yodgor burns wood, a cook who sees his grandfather giving him a bone marrow hits Yodgor on the head with a whip and stains his nose with blood, although there are words that the mentally ill Yodgor says to his grandfather, but they get more complicated. Bakhshi introduces some episodes that are not present in the epic in the description of the events, all of which are indicative of the modernization of epic knowledge. For example, the images of Alpomish's sister Zirak entering the epic events, Ultontoz's brother Karalochin trying to inform Alpomish about his arrival are among such individual creative processes. Modern methods of epic singing do not allow for the full performance of epic texts, but rather form the ability to perform the event in a unit of distance over a certain period of time. In addition, the appearance of the bakhshi when he says "what he wants" does not indicate his talent. One of the first researchers of the folklore of the Turkic peoples, V.V. Radlov commented: "Just as the speaker pronounces the word without thinking about the articulation, if the thought requires a known word, he can sing whatever he wants without thinking about the form, 
only if some external influence begins on the bakhshi.[6.78] The variants of tradition that are passed from the teacher to the student orally are manifested here. The form of performance of the art of bakhshi, formed in stable traditions, passed from mouth to mouth, from generation to generation, was also carried out on the basis of a certain legitimacy. At the same time, it became customary for the bakhshis to adhere to the methods of performing the epic, which they had learned from their masters and were continuing in the live process, and to "respect the creative heritage of their ancestors" [7, 15]. The processes of disruption of the epic tradition, on the other hand, led to the fragmentation of the epic texts. In recent years, such cases have become more pronounced in the performance of young singers such as Sanjar Kubaev and Ilhom Norov.

\section{RESULTS AND DISCUSSION}

Epic memory plays an important role in the transmission of traditional epic texts from generation to generation. Bakhshi has in his memory a knowledge of the general script of the epics, and each time the performer sang the epic, he made extensive use of such a resource and perfected it. Because in the process of teaching epic art, the student must be able to accept and master epic memory, knowledge and worldview, as well as be able to create and execute epic texts based on this trinity. In the art of bakhshi, epic memory is an important tool that preserves creativity, creative ability in the shell of traditions. Its extinction in the creative process leads to a disruption of performance. "If the epic memory, knowledge and worldview are forgotten in the art of bakhshi, then the creative beginning is also lost" [8, 274]. Although Bakhshi does not feel such concepts himself, he applies them directly in the process of learning.

The change in epic memory, knowledge and worldview in the process of live performance is one of the circumstances that leads to a violation of epic traditions. Such processes are also observed in cases such as complicating the description of events in the direction of the epic plot (depiction based on the appearance of written literature), putting all the knowledge of the narrator in one epic, trying to tell differently from existing options, copying episodes from one epic to another. This is the performance of the epic, creating in its variants some kind of composition, even a contradictory image.

The decline in epic memory and knowledge occurs primarily as a result of the influence of socio-cultural factors. The penetration of written literature, cinema, the media, and the global network into the lives of the people has weakened the spiritual need to listen to the bakhshi. "The aesthetic taste of modern man is formed on the basis of the complex aesthetic requirements of written literature; it cannot be satisfied with the aesthetic scale and taste inherent in a folk epic" [9, 7]. As a result, Bakhshi sang in a narrow circle, and his performance was adapted to the modern worldview of the public. The pictorial style of the epic is still not able to convey modern reality and the spiritual experiences of a modern person, his complex life scenes. There are many legends and stories about the fact that epics such as "Alpomish", "Gorogly", "Rustamkhan" were performed for months at a time when epic poetry continued to be traditional and bakhshis took a creative approach to their art.

Whether the epic memory is in harmony with the modern worldview, or is forgotten from 
the memory of the bakhsh, also affects the text of the epic he studied. The transformation of epic memory in bakhshi memory is evident not only in the text of the epic, but also in the form of epic melodies and performances.

However, today in the Kashkadarya and Surkhandarya oases there is an ongoing interest in the art of bakhshi, the demand and need to recite the epic, and such processes are of interest to the younger generation to sing epic. The presence of the audience, the relative continuity of the teacher-student relationship between the bakhshis and the poets, as well as their adherence to it, arouses the desire among young people to study the texts of the epic. However, it should be noted that while the bakhshis try to perform traditional epics, due to today's literary and cultural life, they have a growing sense of authorship, a creative approach to the epic.

"Birth of Sahibkiran”, "Oysuluv" (Ruzi bakhshi Kulturaev), "Ahmad Yassavi", "Temur and Boyazid”, "Samarkand tarovati”, “Kungrad”, "Beva Barchin", "About Qadir bakhshi" doston "(Qahhor Rakhimov)," Alp Kungirotbek "(Chori Umirov)," Kaysar dev "(Ahmad bakhshi Shotora ogli),“ Sanamgul "(Rasul bakhshi Umirov) and others. All this testifies to the modernization of the worldview of today's oasis poets, the growing reflection of the epic process in the spirit of the times. In terms of artistic criteria, it is possible to observe cases of a free creative approach to the events of the epic based on the worldview of the audience. It is as if the bakhshis began to regard themselves as the creators of a new era, which led to the "creation" of the above-mentioned epics, which did not exist in tradition in their work. Bakhshi's modern appearance on the stage enhances not only the performance of epics, but also the national creativity in their repertoire [10].

The literacy of today's bakhshis allows for the free use of published epic texts and samples of written literature in the creative process. All of this is accelerating the gradual extinction of epic performance in oral settings. Such changes in the performance and epic repertoire of the bakhshis led to a breakdown of individual creativity, the texts of the epic. The death of a generation of badihagoy bakhshis, who studied the art of bakhshi orally and passed it on to the oral generations, led to the extinction of the art of bakhshi in a number of regions. Now the teachers did not take their students home for two or three years, but constantly taught them what they knew, identified their talents on a probationary basis, and finished praying.

\section{CONCLUSION}

Today in the oasis of southern Uzbekistan the tradition of performing the epic continues, and the main reasons for its preservation are:

\section{First, the epic atmosphere and ceremony}

The interest of local residents living in the oasis for passion and the desire for generosity and epic poetry continues today. The desire of the older generation to listen to the bakhshi and enjoy their work, and the attempts to invite the bakhshis to weddings, circles and celebrations are also increasing the interest of the younger generation in this art form. As the art of bakhshi has lived side by side with the ritual in its archaic form, it will continue to serve in the ceremonies of our people with new interpretations [11].

\section{Secondly, epic memory, knowledge and worldview}

The presence of a number of masters of the traditional epic, their epic memory, 
knowledge and worldview, the ability to sing and perform epics, as well as teaching the epic to inquisitive youth make it possible to preserve this art in the cultural life of the people.

\section{Third, the benefactor and the audience}

There is a new "audience" in the performance of bakhshis, and there is a feeling of enjoyment of their work. Bakhshi's modern audience is associated with his appearance in the media, audio and video shows and broadcasts. Today, the possibilities of epic performance have expanded. Bakhshis, as a modern performer, are enjoying the performance skills of many people with their theatrical performances, TV, radio and audio and video performances. Bakhshi is now adapting to contemporary epic performing arts without being free in a specially trained audience. In a sense, such processes also contribute to the preservation of the art of bakhshi [12, 227].

\section{Fourth, epic performance and social support}

Particular attention is paid to the preservation and development of intangible cultural heritage, which has become a symbol of our national values, including the art of bakhshi and epic poetry, the full support of the creative work of young poets. Bakhshi-poets' contests and speeches about them in the media, the title of "People's Bakhshi of the Republic of Uzbekistan" was established, Kara and Chori Umirovs, Shomurod Togaev, Shoberdi Boltaev, Abdunazar Poyonov, Qahhor and Abdumurod Rakhimovs, Rasul bakhshi Umirov, Shodmon bakhshi Khojamdiev, The fact that Mahmatmurad and Achil Bakhshi were awarded this title, Ruzi Kulturaev, Shodiqul and Boykul Mirzaev, Panji Bakhshi, Bahrom and Ziyodulla Bakhshi taught the secrets of epic poetry to the student bakhshis ensures the relative preservation of this art.

In general, the folk epic is the ethno-cultural life of the people and its integral part, in which the spiritual beliefs and traditions of the people find a generalized artistic expression. On the other hand, the art of bakhshi and epism lives in the shell of such traditions with its new interpretations and continues to serve generations.

\section{REFERENCES}

1. Mirzaev T. Epos and storyteller. Tashkent: Fan, 2008.

2. Mirzaev T. An epic repertoire of folk singers. Tashkent: Fan, 1979.

3. Kydyrbaeva R.Z .Storytelling skill of manaschi. Frunze: Ilim, 1984.

4. Oyparcha. Epic. Narrators Umir poet Safarov and Bori bakhshi Ahmedov.Tashkent: Ghafur Gulom, 2016. -p. 217.

5. Radlov V.V. Samples of folk literature of the northern Turkic tribes. Part 5. The adverb of the wild-stone Kyrgyz. SPb, 1885. -p. 78.

6. Novikov Yu.A. The storyteller and the biline tradition. SPb, 2000. -p. 15.

7. Putilov B. Epic storytelling. Moscow: Eastern Literature, 1997.

8. Sarimsoqov B. Sample of the classic epic "Alpomish" |/ "Uzbek language and literature", magazine. 1999 №4son. - $p .7$.

9. Ergashev A. KashkadaryaSurkhandarya epic. Tashkent: Fan, 2008.

10. Jumanazarov U. Uzbek folklore and historical reality. Tashkent: Fan, 1991.

11. Bakchiev T. Kyrgyz epic storytellers. Bishkek, 2015. -p. 227. 